\title{
Language and other background factors affecting secondary pupils' performance in Mathematics in South Africa
}

\author{
Sarah J. Howie \\ Centre For Evaluation and Assessment, University of Pretoria, \\ showie@postino.up.ac.za
}

\begin{abstract}
South Africa participated in the Third International Mathematics and Science Study (TIMSS) in 1995 and again in 1999 (TIMSS-Repeat) and in both studies the performance was extremely low compared to the other countries in the studies. In both studies more than $70 \%$ of the pupils wrote the achievement tests in their second or third language. A national option, an English test, was included together with the TIMSS-R mathematics and science tests in an attempt to ascertain the level of the pupils' language proficiency. Furthermore, additional questions pertaining to the pupils and their teachers' exposure and usage of English both within and outside of school were also included in the background questionnaire.
\end{abstract}

In this research project that included more than 8000 pupils in 200 schools, all the items pertaining to English proficiency and language usage and their relationship to mathematics achievement were explored. Partial Least Square analysis was used to explore the relative contribution of these factors to pupils' achievement together with other background variables from the student, teacher and principal questionnaires, resulting in the presentation of a schoollevel, a classroom-level model, a student-level model and a combined class and school-level model. Multi-level analysis was employed whereby a 2-level model (school and class-level and the student-level) was analysed in order to investigate the main factors explaining achievement of South African pupils in mathematics.

The study revealed that the pupils' proficiency of English was a strong predictor of their success in mathematics. A number of other background variables on student and class-level were found to be significant. However, home language and class size were amongst those that were not found to have significant effect on achievement, whilst the effect of socio-economic status had a lesser effect once certain class-level factors were taken into consideration.

\section{Introduction}

This research is a secondary analysis of the performance of the South African pupils in the Third International Mathematics and Science Study-Repeat (TIMSS-R) in which pupils wrote tests in mathematics and science, but in South Africa pupils also had to write an English test, which was included as a national option. TIMSS-R was conducted in 1998/1999 in South Africa and internationally under the auspices of the International Association for the Evaluation of Educational Achievement (IEA). South Africa was just one of the 38 countries participating in the study. However, the South African pupils performance was significantly below that of all other participating countries including other developing countries such as Morocco, Tunisia, Chile, Indonesia and the Philippines. This paper presents some of the final results of a threeyear research project (Howie, 2002) and includes the final Partial Least Square analysis and multi-level analysis of the effect of language and other contextual factors on student and school level.

South Africa faces the challenge of providing quality mathematics education for its multicultural society of 43 million people. The rich diversity of this society is reflected by the large number of official languages of the country. English is spoken as a first language by less than ten percent of the population and is the language of business and government. It is also one of two languages usually used at schools although it is not the most widely spoken language at 
home. However, the issue around the language policy for teaching and learning has become a sensitive and controversial topic in South Africa just as it is in many other post-colonial countries.

\section{Objectives of the study}

The research reported here concentrates on the final outcomes of the exploration of the performance of the South African pupils in mathematics and most especially the relationship between mathematics achievement and pupils' proficiency in English. The factors relating to the pupils performance in mathematics and English language proficiency were explored in relation to the background information that was also collected from the pupils, teachers and principals of the schools included in the study.

The following research questions addressed in this paper are:

1. What is the effect of language on South African pupils performance in mathematics?

2. How does the effect of language relate to other background variables collected at school and student level?

The extent of the pupils' aptitude in English and mathematics was analysed. Every South African pupil in TIMSS-R completed a standardised written skills and language usage test (HSRC, 1990). The performance of the pupils in this test indicates a measure of language proficiency in English. As English language proficiency in South Africa is correlated with other important background variables due to the nature of the country's political past, other background variables were explored and included in a multilevel model developed to address the second research question.

\section{Literature review}

A number of reports and articles have been written on the status of mathematics (and science) education in South Africa (Arnott \& Kubeka, 1997; Kahn, 1993; Taylor \& Vinjevold, 1999; amongst others). Many have commented the poor results achieved in the mathematics matriculation examinations. However, there have been no national surveys on secondary pupils' achievement in mathematics conducted by the Department of Education or other government departments. Only in 2001, was the decision made to introduce sample-based national assessments at grades 3,6 and 9 levels to provide policymakers with information regarding the effectiveness of the education system. Research conducted, that included achievement data, were case studies on local and regional samples (see Maja, Du Plooy, \& Swanepoel, 1999; Monyana, 1996; Rakgokong, 1994; amongst others), which were not nationally representative samples resulting in limited inferences being made from the data.

However, a number of factors have been reported pertaining to the poor performance of pupils in the matriculation examinations and in general (Adler, 1998; Arnott \& Kubeka, 1997; Kahn, 1993; Monyana, 1996; Setati \& Adler, 2000; Taylor \& Vinjevold, 1999). These include: inadequate subject knowledge of teachers, inadequate communication ability of pupils and teachers in the language of instruction, lack of instructional materials, difficulties experienced by teachers to manage activities in classrooms, the lack of professional leadership, pressure to complete examination driven syllabi, heavy teaching loads, overcrowded classrooms, poor communication between policy-makers and practitioners, as well as lack of support due to a shortage of professional staff in the ministries of education. Most of these were reported on the basis of classroom observations and discussions with teachers and other stakeholders. Only Monyana (1996) collected data for the purpose of analysing the factors that had an effect on mathematics performance and utilised inferential statistics. However, there is a study involving data from 100 schools as part of the Quality Learning Project that has also collected background 
data in order to infer reasons for pupils' performance in mathematics (and science) (see Prinsloo, Kanjee, Pfeiffer \& Howie, 2001). In the Third International Mathematics and Science Study (TIMSS) conducted in 1995, the performance of the South African pupils was significantly below that of all the other 40 participants in the study (Howie, 1997; Howie \& Hughes, 1998). TIMSS provided South Africa with the first national representative overview of how South African pupils were performing in mathematics (and science). However, there were significant language and communication problems with South African pupils learning mathematics in a second language. Pupils in all three Grades $(7,8,12)$ showed a lack of understanding of both mathematics questions, and an inability to communicate their answers in instances where they did understand the questions. Pupils performed particularly badly in questions requiring a written answer.

Internationally, research addressing factors related to achievement in mathematics was found using data from, for example Belgium (van den Broek \& van Damme, 2001), and Eastern Europe (Vari, 1997), but most were found in the USA (Sojourner and Kushner, 1997; Teddlie \& Reynolds, 2000, amongst others). No studies were found either nationally or internationally that attempt to link English Language proficiency to mathematics achievement at secondary level using such a comprehensive dataset with data on pupil, class and school levels.

Studies regarding the effects of language on mathematics achievement appear to indicate the importance of language in achievement generally, including mathematics (Berry, 1995; Clarkson, 1991; Tartre \& Fennema, 1995; Young, 1997) and science (Mosoeunyane, 2001; Abraham \& Rambuda, 2001; Torres \& Zeidler, 2002). There seems to be sufficient evidence internationally and some evidence locally to warrant the assessment of language and its relationship to mathematics on a large scale in South Africa.

Clearly there are many factors that have been found on school, class and student levels to have positive and negative effects on mathematics achievement (see Howie, 2002, for a comprehensive discussion). Here summary conclusions are presented in which only references to African research and/or pertaining to less developed countries are included.

The factors on student level discussed in the literature included: socio-economic status (Afrassa, 1998; Cherian, 1992; Howie \& Pietersen, 2001, amongst others), books in the home, parental education, parents occupation (Afrassa, 1998; Eshetu, 1988, Gennet, 1991), parental relationships (Eshetu, 1988), parental pressure, parent's self-concept, pupils' attitudes to mathematics, family size (Behutiye \& Wagner, 1995), jobs in the home (Deresse, Wagner \& Alemaychu, 1990; Daniel, 1995), pupils' aspirations, peer group attitudes, pupils' self concept (Howie \& Wedepohl, 1997), self expectations, pupils' anxiety (Maqsud \& Klalique, 1991), enjoyment of mathematics, attitudes towards maths (Sayers, 1994), reading ability, gender (Afrassa, 1998), age, attitudes towards teachers (Georgewill, 1990), time spent on homework (Afrassa, 1998). Of these most were investigated in this study as well. The exceptions are parents' occupations, parental relationships, parents' self-concept, pupil anxiety, cognitive ability, reading ability and attitudes to teachers. This omission is not because they are not important, but rather due to the limitations of the dataset that was used.

On classroom level, factors found in the literature were the learning environment, teacher's characteristics (including gender) (Monyana, 1996), teacher's personality, streaming, computers, teachers' competence (Georgewill, 1990; Taylor \& Vinjevold, 1999), teacher's confidence, education background, teacher's qualifications (Arnott \& Kubeka, 1997; Mpofana, 1989), teachers' methods, class size (Cohn \& Rossmiller, 1987), time on task, disruptions in class, calculators, content coverage, and assessment. Of these factors, most were explored in the study, the only exceptions being teacher's personality and content coverage. The former not 
having been included in the questionnaires and the latter due to data problems where the data could not be recovered.

Finally on school-level a number of factors have been investigated in previous studies. These included textbooks, teacher quality, time on task, leadership, organisation, management (Riddell, 1997), decision-making, within-school hierarchy, communication, school size, professional development (Cohn \& Rossmiller, 1987), location, commitment, and the controlled environment. In this study, only textbooks, time on task, leadership, decision-making, school size and location were explored, as the other factors were not included in the data collection.

\section{Theoretical framework}

In order to address the objectives of the study, a conceptual model was developed for this research. This model was to allow for the exploration of contextual factors within different levels influencing pupils' achievement in mathematics within the context of South Africa. A summary of the model description is given here whilst a complete description can be found in Howie (2002).

The model was informed largely by Shavelson, McDonnell and Oakes, 1987, as well as other literature discussed in the previous section. The model presents the education system in terms of inputs (including contexts), processes and outputs. The inputs are the policy-related contexts on a national, provincial and local level from which the intended curriculum (in the meaning of what should be taught in schools and learned by the pupils) is also designed and developed. They also include the antecedents: the economic, physical and human resources supplied to different levels of the system; the characteristics of the teachers and the background of the pupils. Inputs into the system affect all the processes of education, which may also be seen as the practice in education. Different processes (relating to what is taught and how it is taught) take place within the districts, schools, and inside the classrooms in terms of the implemented curriculum (in the meaning of what is actually being taught in the classrooms), teaching (in the meaning of the context and conditions under which teachers work) and instruction. The outputs, also seen as the outcomes, eventuate in terms of the achievement of learners in specific subjects such as mathematics; participation in class and school activities, and finally learners' attitudes towards subjects and schooling and aspirations for the future. It is expected that, due to the dynamics of the processes included in the model, there will also be indirect benefits and outcomes, such as improved learner participation partly due to improved curriculum quality.

The model serves as an important theoretical and conceptual basis for the analysis of the TIMSS-R data. As the data were collected on a number of education levels, namely, school, classroom and learner level, the model serves as a guide to explore the causal links for the learners' achievement.

\section{Research design}

The research was divided into two phases. Phase one concentrated on describing the South African pupils' performance in mathematics and provided descriptive information regarding the background characteristics of the pupils, their mathematics teachers and the schools that they attended. However, this is not the focus of this paper and can be found in Howie (2002).

The second phase was an exploratory and analytical phase of the study focusing on the secondary analysis of the TIMSS-R data related to mathematics achievement and a summary of the methods as well as the findings are discussed in this paper. The data were explored to investigate the reasons for the pupils' performance and to explore the inter-relationships of achievement and the background variables revealed by pupils, teachers and the school principal. In particular, the exploratory part of the study was to determine the factors that influence 
mathematics achievement and performance of South African pupils and to ascertain the effect of South African pupils' language and communication skills on their achievement in mathematics.

\section{Sample}

The TIMSS requirements stipulated that a minimum of 150 schools be tested and that a minimum of one class (preferably one whole class) per school be tested. The South African initial sample was expanded to 225 to accommodate the inter-provincial analysis required. The nationally representative sample drawn stratified by province, school sector and medium of instruction. A two-stage stratified cluster sample of 225 schools was randomly selected and stratified according to province, type of education (government or private) and medium of instruction (English and Afrikaans). Tests and questionnaires were administered (by the Human Sciences Research Council based in Pretoria, South Africa) to more than 9000 pupils. Questionnaires were also administered to 200 school principals and 400 teachers of mathematics and science at Grade 8 level. After the data cleaning a representative sample of 194 schools and 8146 pupils was used in the data analysis.

\section{Instruments}

The following instruments were designed and implemented for TIMSS-R: Eight test booklets containing mathematics and science achievement tests which were administered in both English and Afrikaans, pupil questionnaire, mathematics teacher questionnaire, science teacher questionnaire, school questionnaire. The mathematics test can be considered valid for South Africa, as an analysis by South African national department officials showed that $83 \%$ of the achievement test items were covered in the national curriculum for grade 8, whilst it appeared that in all countries (including South Africa) pupils performed similarly on the test items covered by their national curriculum as on the part of the test not covered in the curriculum (Mullis et al., 2000).

As a National Option for South Africa an English language proficiency test was included specifically for South African pupils. This instrument had previously been validated by the Human Sciences Research Council and standardised for Grade 8 Second Language pupils in South African schools (HSRC, 1990). At the time of the TIMSS-R study, this test was the only standardised South African second language test at the Grade 8 level that could be found. Two language education experts evaluated the test and felt that it was still valid. Questions were also included in the TIMSS-R pupils' and teachers' questionnaires, to ascertain the extent and level to which the pupils are exposed to English. They included pupils' home language, ethnic group, the language spoken predominantly by the pupils in the mathematics class, the language used by the mathematics teacher in class, media languages pupils are exposed to and the language of their reading materials. In this research, data from the test booklets, pupil questionnaires, mathematics teacher questionnaires, school questionnaire and the national option were analysed.

\section{Data analysis}

The first step in the analysis plan was to produce frequencies of all the possible school-, classand student-level factors linked to the research questions and the data were explored to make constructs (such as possessions in the home) Thereafter a correlation matrix was made. In the descriptive phase bivariate and multivariate analyses were also done. The correlation matrix was important to identify possible variables linked to achievement, to build constructs and to prepare a basic model for further analysis.

Given that there are a number of variables reported to influence pupils' achievement as well as the vast number of variables in the database, and that some of these were intricately inter- 
related, Partial Least Square analysis (PLS) (Sellin, 1989) was used initially to analyse those student-level and classroom-level factors that influenced pupils' achievement in mathematics. Partial Least Square analysis is a form of multivariate analysis that explores causal relations amongst different variables (factors) and represents these by means of graphic path diagrams (see e.g. Figure 3). These diagrams or causal models illustrate the 'paths' along which the causal influences flow. This type of analysis allows researchers to estimate or predict both the direct and indirect effects of a set of independent variables on a dependent variable (with each path taking into account the effects of all the other variables).

Due to the fact that data were collected on three levels - student-level, class-level and school level, multilevel modelling (Institute of Education, 2000) was applied. Multilevel modelling is a research tool applying multiple regression analysis, that investigates the interaction between variables on the individual (student) level and variables that describe the social groups to which the individuals belong (e.g., schools and classrooms). In this study, multilevel modelling was used to distinguish between the variance in mathematics achievement uniquely explained by student-level factors as opposed to the variance uniquely explained by the classroom and school-level factors and to investigate the individual effects of variables inserted in the model once the multilevel structure of the data is taken into account. As only one class per school was sampled, only two levels could be analysed and this was due to the original TIMSS-R design where class and school are considered one level.

\section{Results}

\section{Results of the mathematics tests}

Overall, South African pupils achieved 275 points out of 800 (standard error, 6.8) in the mathematics test, whilst the international average was 487 . This result is significantly below the mean scores of all other participating countries, including the two other African countries of Morocco and Tunisia as well as that of other developing or newly developed countries such as Malaysia, the Philippines, Indonesia and Chile (see Figure 1). The achievement in mathematics was dominated once again by the Asian countries of Singapore (at the top with 604 scale points), Korea, Chinese Taipei, Hong Kong and Japan who achieved the top five scores.

The province with the highest average scale score for mathematics was Western Cape with 381 scale points, but this was still significantly below the international mean score of 487 . Northern Cape and Gauteng achieved the next highest scores with 318. Pupils from the Limpopo province scored well below all the other provinces with 226 points.

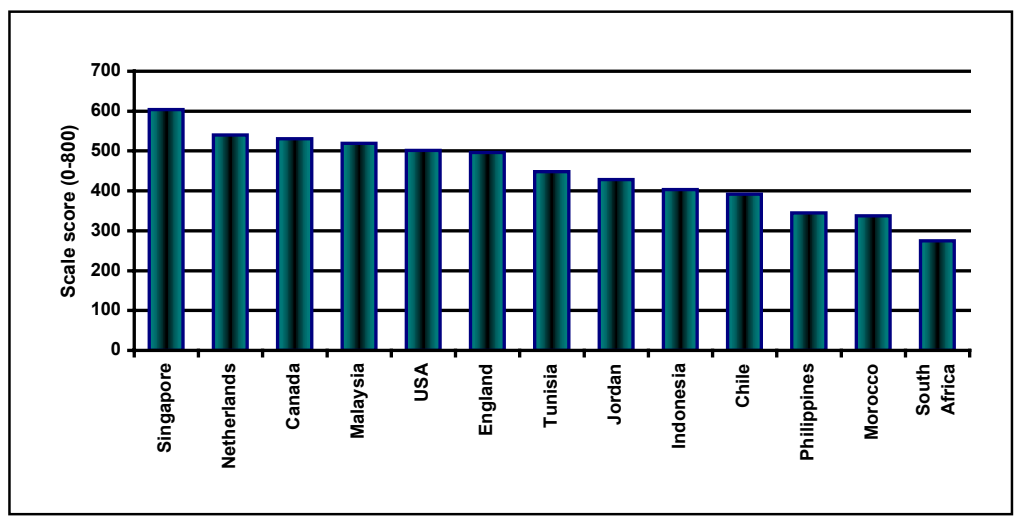

Figure 1: South African mean score compared to mean scores of selected TIMSS-R countries internationally 
The results of pupils' scores are given in Table 1 with reference to the regularity with which the language of the test is spoken at home as this is believed to have an influence on the overall results. The scores appear to reveal a trend that pupils that speak the language of the test more frequently also attain higher scores on the mathematics test. When comparing those pupils that almost always or always speak the language of the test to those that never speak the language of the test, the former achieve scores that are more than 140 points higher than the latter.

Table 1: Mean mathematics scores for South African pupils who always or almost always, sometimes or never speak the language of the test at home

\begin{tabular}{|c|c|c|c|c|c|c|c|c|c|c|}
\hline & \multirow[b]{2}{*}{$\mathbf{N}$} & \multicolumn{3}{|c|}{ Always/almost always } & \multicolumn{3}{|c|}{ Sometimes } & \multicolumn{3}{|l|}{ Never } \\
\hline & & $\begin{array}{l}\% \text { of } \\
\text { pupils }\end{array}$ & Mean & $S E$ & $\begin{array}{l}\% \text { of } \\
\text { pupils }\end{array}$ & Mean & $S E$ & $\begin{array}{l}\% \text { of } \\
\text { pupils }\end{array}$ & Mean & $S E$ \\
\hline $\begin{array}{l}\text { South African } \\
\text { pupils' score }\end{array}$ & 8146 & 23 & 370 & 2.2 & 53 & 259 & 1.6 & 24 & 224 & 1.8 \\
\hline
\end{tabular}

Source: Mullis et al., 2000.

From a comparative analysis of South African pupils' results with other countries in TIMSS-R (see Howie, 2001), some interesting observations were made. More than $70 \%$ of pupils from South Africa, Indonesia, Morocco, Philippines and Singapore did not always speak the language of the test at home. Nonetheless, the mean achievement scores vary considerably across this group of countries and there are also some interesting trends in the data. Pupils in Malaysia generally did considerably better in mathematics than those from Indonesia. Nonetheless, there is a similar trend in both countries where pupils who never speak the language of the test at home, namely $9 \%$ in Indonesia and 10\% in Malaysia, still appeared to outperform those who always or sometimes spoke the language of the test at home. It suggests therefore that the differences between language groups are not only dependent on language. Indonesia for instance is described as a highly diverse country with more than 600 languages and 200 million people (Baker \& Prys-Jones, 1998, p. 375) and yet apparently their pupils do not appear to have been disadvantaged by writing the test in a second language. A similar pattern was also observed for Morocco and the Philippines in mathematics. In Singapore there does appear to be a difference, but yet those who never speak the language of the test at home, still outperform pupils from 33 other countries.

Even looking at the other African countries, the scores of those never speaking the language at home are better in the case of Morocco for mathematics and are comparable for those from Tunisia. This issue needs to be explored further as it appears from the data, that the pupils from other developing countries do not seem to be disadvantaged by writing tests in their second or third language in mathematics or science, however it is not clear why this is so. Important lessons for South Africa may lie in the answers.

In South Africa, pupils who spoke either English or Afrikaans at home achieved higher scores (about 100 points above the national average) than those who did not and. What is illuminating is that children who spoke other languages at home (for example, Greek, Portuguese or Tamil) and therefore also learned in a second language, scored only 20 points on average less than first language speakers. However, children speaking African languages at home attained 100 points less than the other group of second language speakers. No group of pupils came close to attaining the international average for mathematics.

\section{Results of the English language test}

In addition to the mathematics and science tests conducted in TIMSS-R, an English language proficiency test was included that aimed to assess pupils' writing related skills and language usage in English. The test comprised 40 multiple-choice items. Thirty of the forty items had four options, whilst the remaining 10 items had two answer options. 
The overall mean score for the language test was 17 out of $40(42.5 \% ; n=8349)$. The minimum score attained was 0 and the maximum score 40 . In general, the scores for boys and girls were comparable. The scores varied across the nine provinces (see Figure 2) with the wealthiest and most urbanised provinces (Gauteng and Western Cape) attaining the highest overall scores. Thereafter, pupils in the Northern Cape achieved the highest of the remaining seven provinces. This result is consistent with the finding that Afrikaans speaking pupils performed reasonably well on the test as the majority of the Northern Cape pupils tested were Afrikaans speaking. Of some concern is the very low proficiency in English displayed by the Limpopo Province pupils, which was evident from the lowest scores attained of any province. In contrast to other provinces where the maximum score found was 34 points or higher, the maximum score recorded was 27 points out of $40(67.5 \%)$. What is evident from the results is that the language performance follows a similar trend to that of mathematics, meaning that those provinces that performed better in mathematics also tended to perform better in the language test (see Figure 2).

As the test was designed for English second language speakers, it is not surprising that native English speakers performed the best of all language groups ( 25 points out of 40 ), although one might have expected the scores to have been higher given this fact. The Afrikaans speaking children attained the next highest score with 21 points out of 40 . The scores were more or less consistent across the pupils whose main language was an African language. The Tswana and Southern-Sotho speaking pupils attained the highest scores out of those speaking African languages. This may reflect the urbanisation of the people speaking these two languages although other interpretations for this may also exist, for instance the emphasis on English language and communication skills in the former Bophutatswana, where most of the Tswanaspeakers originate.

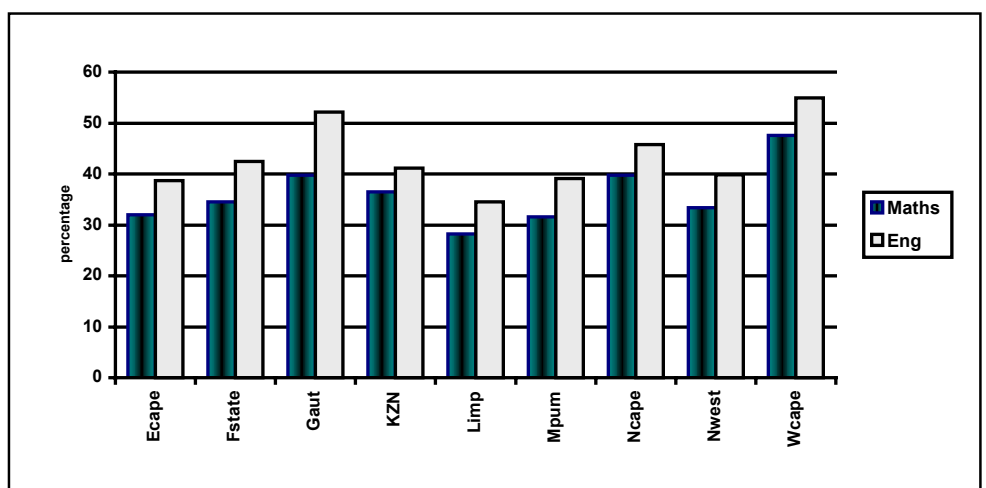

Figure 2: Average percentage correct achieved by South African pupils in mathematics and language per province

\section{PLS exploration of the contextual factors on student, classroom and school}

Three hypothesised models on student, class and school level were analysed using Partial Least Square (PLS) analysis to explore the direct and indirect effects of individual variables on all three levels. The results of these analyses were scrutinised and thereafter the class and school level models were combined into one model and reanalysed. The main results are summarised here and the detailed explanation and discussion of these PLS results can be found in Howie (2002). As an illustration of a PLS model, the student level model is depicted in Figure 3 (see appendix for explanation of the variables). The numbers on the arrows are the so-called beta-coefficients, indicating on a scale $[-1,1]$ the strengths and the direction of the relationship. Sellin (1990) suggests that for large samples (like this sample of students) every coefficient with an absolute value $>0.07$ represents a direct effect of the factor on mathematics achievement, whilst he 
recommends for models with smaller samples (like the school level model) a critical value of 0.10 .

\section{Student-level factors}

Data pertaining to the pupils' home background, their personal characteristics, their aptitude and competencies were explored. A high percentage of variance $(50 \%)$ in the pupils' mathematics score was explained. Six factors were found to have a direct effect on South African pupils' performance in mathematics, namely the pupils' proficiency in English (engtest), their own self concept in terms of mathematics (selfcnp), the language pupils spoke at home (lang), their socio-economic status at home (SES), and whether or not they, their friends and their mothers thought that maths was important (mathim) and language of learning in the classroom (lanlearn).

Figure 3. An example of a PLS model: the student level model (see appendix for explanation of the variables).

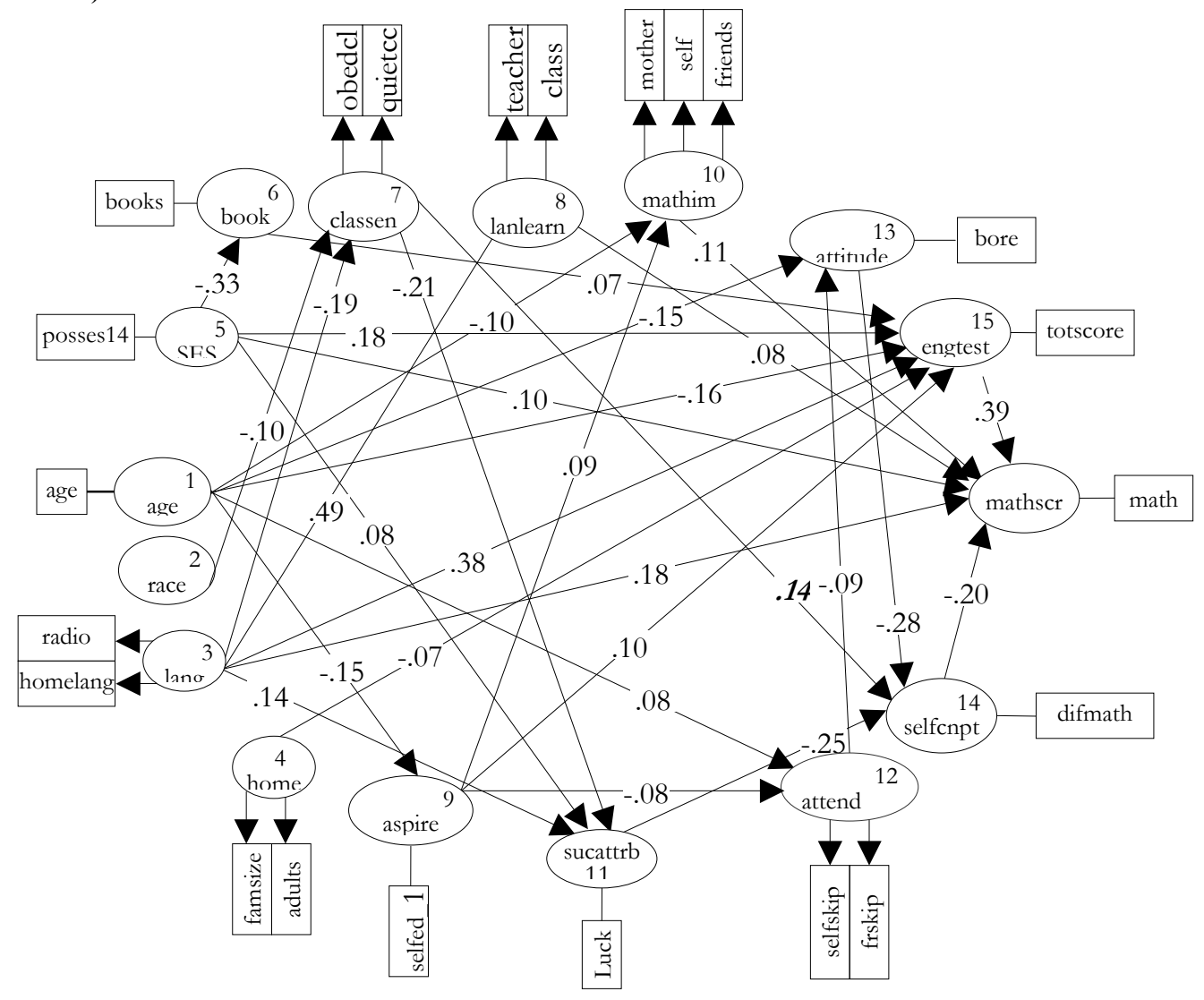

\section{School-only level factors}

Some important aspects of school quality related to school leadership, parent involvement, school profile, physical resources, human resources, autonomy, learning environment and school administration were explored in the data from the school principal's questionnaire. Two important antecedents related to the type of community and the home language of the pupil, were included in the model. Sixty-two percent of the variance in the pupils' scores in mathematics could be explained by three factors at the school level, namely, the community where the school was located, the influence that the teachers union have on the curriculum, and an aggregated 
pupil variable, the extent to which the pupils in the class spoke the language of instruction as their first language.

\section{Classroom-level only factors}

From the mathematics teacher questionnaire, a number of classroom level factors were also explored and these resulted in including the following factors in the model: teachers' gender, teaching experience, teachers' level of education, time spent on activities, lesson preparation, teaching load, time on task, teachers' attitudes, success attribution, teachers' beliefs, teaching style, resources, limitations, and class size. In total, this model explained $46 \%$ of the variance in the pupils' mathematics scores by seven factors - the teachers' attitudes, their beliefs about mathematics, the extent of their teaching and other workload, the size of the class they are teaching, their gender, resources and their dedication towards lesson preparation.

\section{Combined school-class level factors}

Because only one class per school was included in the study, class effects could not be studied independently from school effects. Therefore the school level model and the class-level model were combined and the predictors of mathematics achievement were selected from both models and combined with four aggregated student-level antecedent factors into one model. Therefore factors related to teachers' characteristics, pupils' home background, their aptitude, their attitudes, school quality, teaching requirements, curriculum quality and instructional quality were all explored in one model. Finally, six factors were found that had direct effects on pupils' achievement in mathematics and that explained $27 \%$ of the variance in the mathematics score. These were the location of the school, class size, the attitude of the teacher, teachers' beliefs about mathematics, the teachers' workload (including teaching) and their dedication toward lesson preparation.

\section{Results from the Multi-level analysis}

From the Partial Least Square analysis, the factors that had a direct effect on math achievement were identified and included into the multi-level analysis: language pupils spoke at home, socio-economic status, pupils' English test score, pupils' own self concept in terms of mathematics, whether or not they, their friends and their mothers thought that mathematics was important, language on the radio they most often listen to, size of the class the teachers were teaching, community where the school was situated, language spoken most often in the class by pupils and teachers, teachers' beliefs about mathematics, attitude of the teacher towards the profession, teachers' dedication toward lesson preparation, teachers' teaching load and teachers' total workload. A final variable was included because it was believed to be important from a political perspective, namely the number of pupils enrolled in a school. Ultimately 183 schools and 7651 South African pupils were included in the multi-level analysis.

In the first step of the analysis the only independent variable included was the school of the learner (this is the so-called Null-model). The Null-model in Table 2 shows that more than half of the variance in the mathematics achievement scores is situated on the school level $(55 \%)$ whilst $45 \%$ of the variance can be situated on student level.

In the next step of the multi-level analysis the six student variables were entered successively in the model. The results are summarised in Table 2, column 'Student model - Model 6', in which the numbers represent the regression slopes associated with the various variables (e.g. 5.35 is the regression coefficient associated with 'home language'). Table 2 shows that all regression coefficients are significant, meaning that mathematics achievement tends to be better when the scores are higher on the variables home language, socio-economical status, English Test, selfconcept about mathematics, attitude regarding importance of maths and exposure to the language on the radio. 
The variables English tests, self-concept, importance of mathematics and radio language are described in the Appendix. However one explanatory remark should be made: as self-concept has a negative scale, the negative regression coefficient should be interpreted as 'the more difficulties a learner has with mathematics, the lower the achievement score'. Howie (2002) illustrates these data with two examples to illustrate the influence of the language factor. The model predicts a difference of 57 points on the math achievement scale (with national mean score of 275 scale points) between a pupil that has the mean score on the English test (10 out of 40 points) and a pupil 24 points (the average achieved by native English speakers). As a second example, a pupil who speaks an African language at home and never listens to an English radio station is predicted to score 25.6 points less on the mathematics achievement scale than a student who speaks English at home and always listens to an English radio station. It is therefore very clear that, if one only looks at variables at student level, there is a strong influence of language on achievement in mathematics.

Table 2: Multi-level analysis of the South African TIMSS data with the Math-test score as dependent variable (weighted data)

\begin{tabular}{|c|c|c|c|c|}
\hline \multicolumn{2}{|c|}{ Fixed effect } & $\begin{array}{l}\text { Null-model } \\
\text { (Model 0) }\end{array}$ & $\begin{array}{l}\text { Student Model } \\
\text { (Model 6) }\end{array}$ & $\begin{array}{l}\text { Student-School } \\
\text { (Model 15) }\end{array}$ \\
\hline \multicolumn{5}{|c|}{ student level } \\
\hline \multicolumn{2}{|c|}{ Intercept } & 288 & 278 & 299.5 \\
\hline \multicolumn{2}{|c|}{ Home language } & & $5.35 * *$ & 3.27 \\
\hline \multicolumn{2}{|c|}{ Socio-economic } & & $1.20 * *$ & $.88^{*}$ \\
\hline \multicolumn{2}{|c|}{ English test } & & $4.07 * *$ & $4.00 * *$ \\
\hline \multicolumn{2}{|c|}{ Self-concept } & & $-6.32 * *$ & $-6.29 * *$ \\
\hline \multicolumn{2}{|c|}{ Importance of maths } & & $6.39 * *$ & $6.35^{* *}$ \\
\hline \multicolumn{2}{|c|}{ Radio language } & & $4.75 * *$ & $3.95 * *$ \\
\hline \multicolumn{5}{|c|}{ school level } \\
\hline \multicolumn{2}{|c|}{ Status } & & & $-17.27 * *$ \\
\hline \multicolumn{2}{|c|}{ Beliefs about maths } & & & $-4.46 * *$ \\
\hline \multicolumn{2}{|c|}{ Location } & & & $8.00 * *$ \\
\hline \multicolumn{2}{|c|}{ Class language } & & & $2.59 * *$ \\
\hline \multicolumn{2}{|c|}{ Enrolment } & & & .00 \\
\hline \multicolumn{2}{|c|}{ Work time } & & & $.52 * *$ \\
\hline \multicolumn{2}{|c|}{ Class size } & & & -.27 \\
\hline \multicolumn{2}{|c|}{ Lesson planning } & & & $8.02 *$ \\
\hline \multicolumn{2}{|c|}{ Teaching time } & & & .10 \\
\hline \multicolumn{5}{|c|}{ Random effects } \\
\hline \multicolumn{2}{|c|}{ School level variance } & $6520(55 \%)$ & 2451 & 1336 \\
\hline \multicolumn{2}{|c|}{ Student level variance } & $5342(45 \%)$ & 4570 & 4560 \\
\hline \multicolumn{2}{|c|}{ Difference in deviance } & N/A & $1340^{\#}$ & $132.80^{\#}$ \\
\hline \multicolumn{5}{|c|}{ Explained proportion of variance in math achievement (when compared with Null-model): } \\
\hline \multicolumn{3}{|c|}{ School level variance } & .79 & \\
\hline \multicolumn{3}{|c|}{ Student level variance } & .50 & \\
\hline \multirow{2}{*}{\multicolumn{2}{|c|}{$\begin{array}{l}=7651 \text { pupils } \\
\text { t-value }>1,96, \\
\text { t-value }>2,58,\end{array}$}} & $\begin{array}{l}\text { the mathematic } \\
\text { a number of sc }\end{array}$ & $\begin{array}{l}\text { rs slightly from th } \\
\text { t be included in th }\end{array}$ & ican mean score of 275 on \\
\hline & & $\begin{array}{l}\text { ass per school); } \\
\text { ence interval o } \\
\text { dence interval } \\
\text { is significant ( }\end{array}$ & & \\
\hline
\end{tabular}

A final remark on the Student-model pertains to 'difference in deviance' (see Table 2). The deviance is a measure for the appropriateness as to whether a model is a good representation of the reality represented by the data. The fact that the difference in deviance between the Student model and the Null-model is highly significant means that the Student-model is a highly significant improvement as compared to the Null-model.

The next phase in the multi-level analysis was to enter the nine school level variables, resulting 
in the 'Student-School model', also called model 15 as the model is based on 15 independent variables. The results are summarised in the final column of Table 2. In total, 11 of the 15 factors were found to be significant predictors of South African pupils' achievement in mathematics. Enrolment, class size, teaching time and home language appeared not significant in the Student-School model. Once the school-level variables were entered, the effect of home language, which was significant in the Student model, lost its significance as consequence of the school level variables such as location of the school. On the other hand, the English test score again appears to be one of the most significant (see Howie, 2002). Another result that can be derived from the full model is that $S E S$ is no longer significant (see Howie, 2002). The strength and significance of the school-level variables compensated for the pupil variables resulting in home language and SES losing their significance in the multi-level analysis.

The quality of the Student-School model as the best one in representing the relationship between the independent variables and achievement can be shown from two other parts of Table 2. At first, the difference in deviance between the Student-School model (model 15) and the Student-model (model 6) is significant indicating that the Student-School model is superior. Furthermore, as can be concluded from the lowest part of Table 2, the strength of the StudentSchool model is also illustrated by the variance in mathematics achievement explained by this model, being $79 \%$ of the variance at school level, and $50 \%$ of the variance at student level.

In conclusion, once all the predictors are added to the model, most of the school-level variance in pupils' achievement scores could be explained in the Student-School model. This is not the case for the student-level variance, as a large percentage of the variance on student level $(50 \%$ of the $45 \%$ in the Null-model) could not be explained by the predictors (including a number of language related variables) used in this model. This result may be due to the fact that other variables that are not included in this study are important as well. For example, cognitive ability was not measured in this study, but was included in the Belgian-Flemish study as a national option. Van den Broek and Van Damme (2001) show that in Belgium this variable explains a great deal of variance on student level and explains in fact more than any other single variable in their multi-level model. Clearly more research is needed here for South Africa.

However, the predictors did explain, for the South African data, a high percentage of the variance between schools. This finding means that a large part of the differences between schools in pupils' mathematics achievement can be attributed to these variables. The StudentSchool model indicates that significant predictors for how pupils in different schools perform in mathematics are the pupils' performance in the English test, the socio-economic status (to a lesser extent), the pupils' self concept, the pupils' perception of the importance of mathematics, their exposure to English, how pupils' maths teachers perceive their professional status, pupils' maths teachers beliefs about mathematics, the location of the school, the extent to which English is used in the classroom, the amount of time teachers spend working and the amount of time teachers spend in lesson planning. They are also significant predictors of how well pupils' perform in the same school (within-school variance), but to a lesser extent. Noteworthy is that two of these variables have a negative effect, teachers' perception of their status and their beliefs about mathematics. The stronger the teachers' ideas about mathematics and the perception about the status of the profession are, the poorer their pupils perform in mathematics. This observation should not be looked at in isolation, but in conjunction with the other variables that have a significant effect on mathematics achievement, but further discussion is beyond the scope of this article.

\section{Conclusion and reflections}

The first research question addressed the effect of language on South African pupils' performance in mathematics. This research shows that in South Africa, pupils tended to achieve 
higher scores in mathematics when their language proficiency in English was higher and were more likely to attain low scores in mathematics when their scores on the English test were low. Those that spoke English or Afrikaans at home tended to achieve higher scores in mathematics. Alternatively, children from homes where African languages were used were more likely to achieve lower scores. Pupils in classes where the pupils and the teachers mostly interacted in the official media of instruction (English or Afrikaans) were more likely to achieve better results in mathematics.

A key finding from this research is that pupils who spoke either English or Afrikaans at home achieved higher scores in both the mathematics and the English tests than those who did not. There is often a mismatch in many cases regarding the language of the pupil and the language of the teacher. With the increasing heterogeneity of South Africa's schools in culture and language, offering children the opportunity to learn in their own home language is becoming increasingly challenging, as is also illustrated by other (qualitative) studies in South Africa about the relationship between mathematics and language (see e.g. Adler, 1998; Setati \& Adler, 2000)

With regard to language another key finding was that the average English test score was very low and the majority of pupils' English language proficiency was poor. Pupils speaking African languages had very low English language proficiency as compared to other second language learners. Furthermore, there is no room for complacency as native English speakers as a group did not perform substantially better than the Afrikaans-speaking group given that this was an English second language test. The low proficiency may be linked to another finding from the research (see Howie, 2002) that more than two-thirds of pupils had very few books in the home It is clear that an urgent and intensive intervention is needed in both English as a discipline in the schools and as a medium of instruction. Above all, children need to be encouraged to read in their leisure time, but they also need to be given opportunities to write in English more so than at present, so that they become familiar in articulating thoughts and knowledge in English. Such an intervention should be targeted to all children, not only the second language speakers.

The second research question focused on how does the effect of language relate to other background variables collected at school and student level. The Student-model (model 6) shows that in addition to language of the home and English proficiency other variables such as SES, self-concept of the learner (about having difficulty with mathematics) and importance of mathematics (according to mother, friends and the learner) are also related to mathematics achievement.

The Student-School model shows the influence of the location of the school in rural or urban areas on mathematics achievement, which is not surprising given the under-development in rural areas in South Africa. However, as $50 \%$ of South Africa's population live in rural areas, the fact that students attending school in rural areas perform worse in mathematics than those attending schools in urban areas should be of serious concern to the education and other authorities and policy-makers. An interesting outcome was the strength of teachers' attitudes, beliefs and dedication as predictors of pupils' achievement. Teachers with strong mathematical pedagogical beliefs and who believed that mathematics is primarily a formal way of representing the real world; that mathematics is primarily a practical and structured guide for addressing real situations; if students are having difficulty an effective approach is to give them more practice by themselves during the class; that more than one representation (picture, concrete material, symbol set etc) should be used in teaching a maths topic; the mathematics should be learned as sets of algorithms or rules that cover all possibilities; and that basic computational skills on the part of the teacher are sufficient for teaching secondary school maths; were also those whose pupils were more likely to achieve lower results. This finding may mean that the teachers with stronger beliefs 
have less content knowledge and less understanding about the philosophy of mathematics perhaps due to their training or lack thereof. This may also result in teaching pupils through rote learning whilst they answered the questionnaire in a way that reflects the philosophy of the new South African curriculum, namely pupil-centred and problem-based teaching. On the other hand, teachers who had weaker beliefs may reflect a group of teachers who had good training, have a good content knowledge and have confidence in their preparation to teach, but stick to traditional teaching methods in contrast to those advocated by the new curriculum. Pupils of such teachers may have performed better on the TIMSS-R test, a test, which has been criticised by proponents of realistic mathematics in the Netherlands as too traditional in its design and content. Further investigation of teachers' beliefs in relation to pupils' achievement is needed.

Teachers with feelings of being appreciated by society and their pupils were more likely to produce pupils with lower results. This finding could be due to the fact that these are teachers in more rural areas who are highly regarded by their communities, as they are well educated compared to others in those communities. However, schools in these same communities are also poor and lack resources and pupils come from poor homes and have much exposure to the languages of learning than their urban counterparts. So, although teachers feel affirmed, they are also challenged by the conditions in their schools, which results in pupils attaining lower scores. On the other hand teachers who feel less affirmed work in better conditions in urban areas and where their pupils come from different background. Teachers' commitment appears to play a key role in pupils' performance. Pupils whose teachers spent more time with work related activities at school tended to achieve higher results in mathematics, although the amount of time that, teachers spent actually teaching had no effect. Likewise, the amount of time that teachers spent preparing lessons resulted in pupils being more likely to achieve higher results.

The lack of effect of class size as a predictor of achievement confirms previous findings in studies of developing countries. In the case of South Africa, those classes with large numbers of pupils (on average 50 pupils) are also those at schools with poor conditions described earlier and therefore it is possible that a type of bottom effect is felt here and therefore, the effect of the actual number of pupils is slight.

These findings are significant against the background of the situation in many South African schools, particularly in those where there are African pupils taught by African teachers. In these schools the conditions are the worst: limited resources and facilities, large percentages of underqualified teachers, pupils from poor socio-economic backgrounds and instruction occurs in a secondary language.

The findings give rise to a number of reflections on the relationship between language and achievement in relation to the language policy implemented by the South African government. The difficulty of not being able to communicate fluently in a common language is leading to increased frustration for the teacher, disorientation on the part of the child, a slow rate of learning, disciplinary problems and teacher centred instruction. Although teachers are aware of the national language policy, they may have very different interpretations of it (Setati, 1999). The majority of parents, pupils and teachers perceive English as the gateway to global opportunities and therefore many want the pupils to participate in their education through the medium of English. The implementation of the language policy needs reassessing regarding its feasibility and the desires of the community. Unless, some hard decisions are taken, and quickly, by decision-makers, pupils and teachers will continue to struggle and pupils will underperform in mathematics and other subjects. If, as the majority of parents seem to desire, English is increasingly used then the necessary support mechanisms need to be put into place including intensive language training of second language teachers who will be teaching through the medium of English. If on the other hand, the decision is made to teach in mother tongue beyond 
grade 5, the ramifications are enormous considering that in urban environments, almost all the official languages are found as well as increasingly more foreign languages (from elsewhere in Africa and beyond). Segregating children and indeed teachers in terms of language (as clearly offering 11 languages of learning will be impossible within a single school) will be an enormous task and may reverse the cultural integration beginning to take place. Of course, in rural areas where one language is almost always clearly dominant, it may be more feasible. The danger of considering only one approach in the language policy, albeit an important one, (for example only considering cultural identity or the political perspective); is that the multiple functions of schooling will be ignored. The curriculum and pupils' education have to fulfil the desires of society namely, that of educating the young towards being responsive citizens in a democratic society, of attaining certain basic knowledge and skills, being prepared for the workplace and/or further education and acquiring adequate social and interpersonal skills. The government has to take a firm lead in finding the appropriate balance between these perspectives, since if this decision is left to the schools, the status quo will remain.

In conclusion, the strength of the language component represented in a number of variables that have strong effects on mathematics achievement is clear. Moreover, the dedication of the teacher matters with regard to their pupils' achievement and the location of the school is further an important predictor of South African pupils' achievement in mathematics. In the past few years, some progress has been made to address shortcomings in South African schools. Although significant progress has been made with regard to administrative restructuring, policy development and infra-structural improvements nonetheless, the quality of education that the majority of pupils are receiving is far from satisfactory. The study (Howie, 2002) highlighted the most significant predictors of mathematics (of which language is only one) within the scope of the data available and has raised a number of questions and issues that are believed to be pertinent to the future development of South African education, in particular in mathematics. The challenges abound within the education system of this country and in addition to the issues of access and equity the most important challenge awaiting now is that of quality.

\section{References}

Abraham, J. \& Rambuda, A.M. (2001). Language as a barrier preventing the learning of science by Grade 12 learners. Http://www.pentech.ac.za/pil88/abstract1.htm.

Adler, J. (1998). A language for teaching dilemmas: Unlocking the complex multilingual secondary mathematics classroom. For the Learning of Mathematics, 18, 24-33.

Afrassa, T.M. (1998). Mathematics achievement in the lower secondary school stages in Australia and Ethiopia: a comparative study of standards of achievement and student-level factors influencing achievement. Unpublished PhD. Thesis. Adelaide: Flinders University of South Australia, School of Education.

Arnott, A. \& Kubeka, Z. (1997). Mathematics and science teachers: Demand, utilisation, supply, and training in South Africa. Johannesburg: Edusource.

Baker, C. \& Prys-Jones, S. (1998). Encyclopedia of bilingualism and bilingual education. Clevedon: Multilingual Matters.

Behutiye, N. \& Wagner, J. (1995). Some aspects of primary school pupils' cognitive development and their relationship to scholastic achievement. Addis Ababa: Curriculum and Evaluation and Educational Research Division, Institute for Curriculum Development.

Berry, J.W. (1995). Learning mathematics in a secondary language: Some cross-cultural issues. For the learning of Mathematics, 5(2), 18-23. 
Cherian, V.I. (1992). Family influences on scholastic achievement. Inaugural address delivered on accepting the chair of Psychology of Education at the University of the North on 28 October 1992, Sovenga.

Clarkson, P.C. (1991). Bilingualism and Mathematics Learning. Australia, Geelong: Deakin University. Cohn, E. \& Rossmiller, R.A. (1987). Research on effective schools: Implications for less-developed countries. Comparative Education Review, 31, 377-399.

Daniel, D. (1995). School attendance and achievement among boys and girls: The case of selected grade six students in Addis Ababa. Proceedings of the National Workshop on Strengthening Educational Research. Addis Ababa: Institute of Educational Research, Addis Ababa University, 253-264.

Deresse, M., Wagner, J. \& Alemaychu, M. (1990). Factors affecting achievement of lower primary school pupils. Addis Ababa: Institute for Curriculum Development and Educational Research.

Eshetu, A. (1988). Comparative study of family background of high achievers and low achievers at Entoto technical, vocational and academics schools. Unpublished BA thesis. Addis Ababa University, Faculty of Education.

Gennet, J (1991). Women in Education: A study of academic performance and participation of female students in high schools. Addis Ababa. Addis Ababa: Addis Ababa University, Department of Business Education, Faculty of Education.

Georgewill, J.W. (1990). Causes of poor achievement in West Africa School Certificate Mathematics Examinations in Rivers State secondary schools, Nigeria. International Journal of Mathematics in Science and Technology, 21, 379-386.

Howie, S.J. (1997). Mathematics and science performance in the middle school years in South Africa: A summary report on the performance of the South African students in the Third International Mathematics and Science Study. Pretoria: HSRC.

Howie, S.J. (2001). Mathematics and Science Performance in Grade 8 in South Africa 1998/1999: TIMSS$R 1999$ South Africa. Pretoria: HSRC report.

Howie, S.J. (2002). English language proficiency and contextual factors influencing mathematics achievement of secondary school pupils in South Africa. Enschede: Doctoral dissertation, University of Twente.

Howie, S.J. \& Hughes, C.A. (1998). Mathematics and science literacy of final-year school students in South Africa: Third International Mathematics and Science Study. Pretoria: HSRC.

Howie, S.J. \& Pietersen, J.J. (2001). Mathematics literacy of final year students: South African realities. Studies in Educational Evaluation, 27(1), 7-26.

Howie, S.J. \& Wedepohl, P.T. (1997). The "crisis" in science and mathematics education in South Africa. A paper presented at the British Educational Research Association conference, York, England, Sept 1997.

Human Sciences Research Council (HSRC) (1990). Achievement Test English Second Language Standard 6. Ref. 2564/2. Pretoria: HSRC, Institute for Psychological and Edumetric Research.

Institute of Education (2000). MlwiN: A visual interface for multilevel modelling. Version 1.10. Multilevel Models project, University of London.

Kahn, M. (1993). Building the base: Report on a sector study of science and mathematics education. Pretoria: Commission of the European Communities. 
Maja, B.I., du Plooy, J. \& Swanepoel, Z. (n.d.). Access to learning: The enabling conditions for successful learning environments. Unpublished.

Maqsud, M. \& Khalique, C.M. (1991). Relationships of some socio-personal factors to mathematics achievement of secondary school and university students in Bophutatswana. Educational Studies in Mathematics, 22, 377-390.

Monyana, H.J. (1996). Factors related to mathematics achievement of secondary school pupils. M. Ed. Thesis. University of South Africa. Unpublished.

Mosoeuyane, M.G. (2001). The relationship between language scores and science scores of 538 Junior Certificate students in Lesotho.Http://www.pentech.ac.za/pil88/abstract30.htm.

Mpofana, W.S. (1989). A didactical study of unsatisfactory classroom interaction as a factor related to the high failure rate in senior secondary schools in mathematics in KwaZulu. M.Ed. University of the Orange Free State. Bloemfontein.

Mullis, I., Martin, M., Gonzalez, E.J., Gregory, K.D., Garden, R.A., O'Connor, K.M., Chrostowski, S.J. \& Smith, T. (2000). TIMSS 1999 International Mathematics Report: Findings From IEA's Repeat of the Third International Mathematics and Science Study at the Eighth Grade. Chestnut Hill: Boston College.

Prinsloo, C., Kanjee, A, Pfeiffer, C. \& Howie, S.J. (2001). Baseline Study Technical Report. Teaching and Learning conditions. Pretoria: HSRC.

Rakgokong, L. (1994). Language and the construction of meaning associated with division in primary mathematics. In M. Glencross (Ed.), Proceedings of the Second Annual Meeting of the Southern African Association for Research in Mathematics and Science Education. Umtata: University of Transkei.

Riddell, A. (1997). Assessing designs for school effectiveness research and school improvement in development countries. Comparative Education Review, 41, 178-204.

Sayers, R. (1994). Gender differences in mathematics education in Zambia. Educational Studies in Mathematics, 26, 389-403.

Sellin, N. (1989). PLSPATH, Version 3.01. Application Manual. Hamburg: University of Hamburg.

Sellin, N. (1990). On aggregation bias. In K.C.Cheung, J.P. Keeves, N. Selling\& S.C. Tsoi, The analysis of multivariate data in educational research: studies of problems and their solutions. International Journal of Educational Research, 14, 257-268.

Setati, M. (1999). Innovative language practices in the classroom. In N. Taylor \& P. Vinjevold (Eds.), Getting learning Right. Johannesburg: Joint Education Trust.

Setati, M. \& Adler, J. (2000). Between languages and discourses: Language practices in primary multilingual classrooms in South Africa. Educational Studies in Mathematics, 43, 243-269.

Shavelson, R.J., McDonnell, L.M. \& Oakes, J. (1987). Indicators for monitoring mathematics and science education: a sourcebook. Santa Monica, CA, USA: The RAND Corporation.

Sojourner, J. \& Kushner, S.N. (1997). Variables that impact the education of African-American students: parental involvement, religious socialisation, socio-economic status, self-concept and gender. Paper presented at the Annual Meeting of the American Education research Association. Chicago, Illinois, March 24-28.

Tartre, L.A. \& Fennema, E. (1995). Mathematics achievement and gender: a longitudinal study of selected cognitive and affective variables (grades 6-12). Educational Studies in Mathematics, 28, 199-227. 
Taylor, N. \& Vinjevold, P. (eds) (1999). Getting Learning Right. Johannesburg: Joint Education Trust.

Teddlie, C. \& Reynolds, D. (2000). The international handbook of school effectiveness research. London: Falmer Press.

Torres, H.N. \& Zeidler, D.L. (2002). The effects of English language proficiency and scientific reasoning skills on the acquisition of science content knowledge by Hispanic English language learners and native English language speaking students. Electronic Journal of Science Education, 6(3).

Van den Broek \& Van Damme (2001). The effects of school, class and student characteristics on mathematics education in Flemish TIMSS-R data. Paper presented at the European Conference on Educational Research, Lille, France, 5-8 September.

Vari, P. (1997). Monitor '95. National assessment of student achievement. Budapest: National Institute of Public Education.

Young, D.J. (1997). A multi-level analysis of science and mathematics achievement. Paper presented at the Annual Meeting of the American Educational Research Association in Chicago, Illinois, March 24-28, 1997. 


\section{Appendix 1}

\begin{tabular}{|c|c|c|c|}
\hline $\begin{array}{l}\text { LATENT } \\
\text { VARIABLES }\end{array}$ & $\begin{array}{l}\text { MANIFEST } \\
\text { VARIABLES }\end{array}$ & DESCRIPTION & SCORING \\
\hline MATHSCR & МАTH & $\begin{array}{l}\text { Student mean score on TIMSS- } \\
\mathrm{R} \text { mathematics test }\end{array}$ & Score out of 800 points \\
\hline ENGTEST & TOTSCORE & $\begin{array}{l}\text { Student mean score on } \\
\text { English language proficiency } \\
\text { test }\end{array}$ & Score out of 40 points \\
\hline RACE & RACE_1 & $\begin{array}{l}\text { Race of student: African, } \\
\text { Coloured, Indian, White, } \\
\text { Asian }\end{array}$ & $\begin{array}{ll}\text { 1. } & \text { African } \\
\text { 2. Asian } \\
\text { 3. } \text { Coloured } \\
\text { 4. Indian } \\
\text { 5. White }\end{array}$ \\
\hline AGE & AGE_1 & Age of student & Number of years \\
\hline \multirow[t]{2}{*}{ LANG } & RALANG_1 & $\begin{array}{l}\text { Language on favourite radio } \\
\text { station }\end{array}$ & $\begin{array}{l}\text { 1. All other langs } \\
\text { 2. Afrikaans } \\
\text { 3. English }\end{array}$ \\
\hline & HOMELANG & $\begin{array}{l}\text { Language spoken most often } \\
\text { at home }\end{array}$ & $\begin{array}{ll}0 . & \text { Other languages } \\
\text { 1. African languages } \\
\text { 2. Afrikaans } \\
\text { 3. } & \text { English }\end{array}$ \\
\hline \multirow[t]{2}{*}{ HОМЕ } & FAMSIZE & $\begin{array}{l}\text { Number of people living in } \\
\text { the home }\end{array}$ & - \\
\hline & $\begin{array}{l}\text { PARENT } \\
\text { (COMPOSITE) }\end{array}$ & $\begin{array}{l}\text { Whether students have } 2 \\
\text { parents }\end{array}$ & $\begin{array}{l}0=\text { no } \\
1 \quad=\text { yes }\end{array}$ \\
\hline воок & BOOKS & Number of books in the home & $\begin{array}{ll}\text { 1. } & 0-10 \\
\text { 2. } & 11-25 \\
\text { 3. } & 26-100 \\
\text { 4. } & 101-200 \\
\text { 5. } & \text { more than } 200\end{array}$ \\
\hline SES & $\begin{array}{l}\text { POSSES10 } \\
\text { (COMPOSITE) }\end{array}$ & $\begin{array}{l}\text { Computer, electricity, tap } \\
\text { water, tv, CD player, radio, } \\
\text { own bedroom, flush toilets, } \\
\text { car ( } 9 \text { items) }\end{array}$ & $\begin{array}{ll}0 . & \text { no } \\
1 . & \text { yes }\end{array}$ \\
\hline CLASSENV & $\begin{array}{l}\text { QUIETCL } \\
\text { OBEDCL }\end{array}$ & $\begin{array}{l}\text { Class climate items } \\
\text { Extent to which the students } \\
\text { report that students in their } \\
\text { classes are quiet in class, are } \\
\text { obedient in class }\end{array}$ & $\begin{array}{l}\text { Scale of }(-) 1-4(+) \\
\text { Strongly agree to strongly disagree } \\
\text { Scale of }(-) 1-4(+) \\
\text { Strongly agree to strongly disagree }\end{array}$ \\
\hline
\end{tabular}




\begin{tabular}{|c|c|c|c|c|}
\hline $\begin{array}{l}\text { LATENT } \\
\text { VARIABLES }\end{array}$ & $\begin{array}{l}\text { MANIFEST } \\
\text { VARIABLES }\end{array}$ & $\begin{array}{l}\text { TIMSS-R } \\
\text { VARIABLES }\end{array}$ & DESCRIPTION & SCORING \\
\hline LANLEARN & $\begin{array}{l}\text { LANLEARN } \\
\text { (COMPOSITE) }\end{array}$ & & $\begin{array}{l}\text { Extent to which both } \\
\text { student and teacher speak } \\
\text { language of instruction in } \\
\text { maths class }\end{array}$ & $\begin{array}{l}\text { 1. language spoken at } \\
\text { home if not } \\
\text { English/Afrikaans } \\
\text { 2. sometimes } \\
\text { English/Afrikaans } \\
\text { 3. most of the time } \\
\text { English/Afrikaans } \\
\text { 4. always English/ } \\
\text { Afrikaans }\end{array}$ \\
\hline МАТНIMPT & $\begin{array}{l}\text { MATHIMPT } \\
\text { (COMPOSITE) }\end{array}$ & $\begin{array}{l}\text { BSBGMIP2 } \\
\text { BSBGSIP3 } \\
\text { BSBGFIP2 }\end{array}$ & $\begin{array}{l}\text { Extent to which students', } \\
\text { Mother, friends think that } \\
\text { maths is important ( } 3 \\
\text { items) }\end{array}$ & $\begin{array}{l}\text { Scale of }(+) 1-4(-) \\
\text { strongly agree to strongly } \\
\text { disagree }\end{array}$ \\
\hline ASPIRE & SELFED_1 & GENEDSE & Aspirations to education & $\begin{array}{l}\text { 1. some secondary } \\
\text { 2. finished secondary } \\
\text { 3. finished technikon } \\
\text { 4. some university } \\
\text { 5. finished university }\end{array}$ \\
\hline ATTEND & $\begin{array}{l}\text { ATTEND } \\
\text { (COMPOSITE:S } \\
\text { ELFSKIP, } \\
\text { FRSKIP) }\end{array}$ & $\begin{array}{l}\text { BSBGSSKP } \\
\text { BSBGFSKP }\end{array}$ & $\begin{array}{l}\text { Extent to which student or } \\
\text { students' friends skip } \\
\text { school ( } 2 \text { items })\end{array}$ & $\begin{array}{l}\text { Scale of }(+) 0-4(-) \\
\text { never, once or twice, three } \\
\text { or four times, five or more }\end{array}$ \\
\hline SELFCNPT & DIFMATH & MATHMYT_1-5 & $\begin{array}{l}\text { The extent to which } \\
\text { student reports having } \\
\text { difficulty with maths ( } 5 \\
\text { items) }\end{array}$ & $\begin{array}{l}\text { Scale of }(-) 1-4(+) \\
\text { Strongly agree to strongly } \\
\text { disagree }\end{array}$ \\
\hline SUCATTRB & LUCK & MATHDOW2 & $\begin{array}{l}\text { If the student attributes } \\
\text { success to Luck }\end{array}$ & $\begin{array}{l}\text { Scale of }(-) 1-4(+) \\
\text { Strongly agree to strongly } \\
\text { disagree }\end{array}$ \\
\hline ATTITUDE & BORE & MATHBORE & $\begin{array}{l}\text { If student finds maths } \\
\text { boring }\end{array}$ & $\begin{array}{l}\text { Scale of }(-) 1-4(+) \\
\text { Strongly agree to strongly } \\
\text { disagree }\end{array}$ \\
\hline
\end{tabular}

